\title{
Comparison growth of Candida albicans in alternative media and semi-synthetic on fisheries cerumen in bastiong karance Ternate City
}

\author{
Erpi Nurdin \& Lailatul Ukhdiyah Syarifudin
}

\author{
Medical Technology Laboratory, Poltekkes Kemenkes Ternate, Ternate City, Maluku Utara
}

\begin{abstract}
Otomycosis is an inflammatory process in the ear canal caused by a fungal infection. The activity of fishermen on the high seas at night or during the day is often at risk of contracting fungal diseases, because their workplaces are in the open air and in wet and humid areas favored by fungi. Work as a fisherman also makes them often exposed to direct sunlight so that the body's temperature rises, the body will produce sweat and cause the ear wax to be disturbed. Semi-synthetic media such as PDAs have sufficient carbohydrate content so that they are good for fungal growth. This media is pretty much needed in fungal breeding both in the laboratory and in agriculture. But the price of this media is quite expensive besides that not all chemical shops provide it, while the needs of PDA media are increasing so that another alternative is needed to replace the fungal culture media. This research is instrumental with a cross sectional approach and aims to find out the level of significance of the differences in the growth of Candida albicans against alternative media for agar dextrose agar and semi-synthetic Potato Dextrose agar (PDA). The sampling technique was non-random with a purposive sampling design of 46 people. The sample was then isolated on a semi-synthetic PDA media and alternative media to see differences in the growth of Candida albicans. Based on the research that has been carried out, it is concluded that there are 38 samples of respondents detected positively Candida albicans on semi-synthetic media (PDA) and alternative media, and based on the results of data processing obtained $p$ value $0,000<0.05$ which indicates that there are very significant differences in growth Candida albicans between semi-synthetic media (PDA) and alternative media.
\end{abstract}

\section{Article History}

Received 11 June 2020

Accepted 30 June 2020

Keyword

Candida albicans, Alternative Media, Potato Dextrose Agar.

\section{Introduction}

Indonesia is a country that is geographically located at 6 northern latitudes - 11 south latitudes, 95 east longitude to 141 west longitude. With such a geographical position, Indonesia is located in the tropics. It affects the climate, weather, humidity and high rainfall and heat throughout the year. This facilitates the emergence of diseases caused by fungi, including Otomikosis (Windu, 2010). 
Otomycosis is an inflammatory process in the ear canal caused by a fungal infection. Otomycosis is a form of disease that is commonly found throughout the world. The frequency varies depending on differences in geographic zones, environmental factors, and also time. Otomycosis is often found in ENT (Ear, Nose, Throat) clinics and the prevalence reaches $9 \%$ of all patients who show symptoms and signs of otitis externa with Candida $s p$ and Aspergillus $s p$ as the most fungal species obtained from their oscillates (Sukardi, 2009).

Many factors have been identified as predisposing to otomycosis, including humid weather, the presence of cerumen, ear instrumentation or ear equipment such as hearing aids, immunocompromised patient status, hot and humid climate, and increased use of topical steroids and antibiotics. Recommended treatment includes local debridoment, stopping use of topical and local or systemic antibiotics (Dwi Hapsari, 2011).

The ear canal is connected to the outside air by a narrow orifice, so that it can function as an excellent breeding ground for bacterial and fungal growth. At a relative humidity above $80 \%$, the epithelial horn layer can absorb water from the air in large quantities. Increasing the contents of the keratin liquid in the pilosebaseus causes swelling and obstruction of the orifice which results in the loss or reduction of cerumen formation. The formation of the affected cerumen will cause a fungal infection in the external ear called otomycosis. Cerumen contains protein, amino acids, mineral ions, lysozyme, immunoglobulins and fatty acids which can inhibit the growth of bacteria and fungi (Sedjawidada, 2009).

From previous research data in 2009, it was found that the incidence of Fungal Colony in Ear Infection Patients in ENT clinic (Ear, Nose, Throat) Hasanuddin University Hospital, from a total sample of 103, a fungal colony was found on culture media with Aspergillus niger 26.6 \%, Aspergillus fumigatus 37.5\%, and Candida albicans 26.9\% (Sedjawidada, et al, 2009).

The activity of fishermen on the high seas at night or during the day is often at risk of contracting fungal diseases, because their workplaces are in the open air and in wet and humid areas favored by fungi. The work as fishermen also makes them often exposed to direct sunlight so that the body's temperature rises, the body will produce sweat and cause the ear wax to be disturbed. Ear canal is one of the places that is easily infected by fungus because the atmosphere is dark and warm makes the fungus easily grow because it gives high humidity which is suitable as a fungal habitat. In addition, most fishermen also pay little attention to personal hygiene and health.

Bastiong Karance is one of the villages located in the coastal area of Ternate City, a village located in Ternate Island Subdistrict, Ternate City, North Maluku Province. Geographically, the Bastiong Karance sub-district is located in the South Ternate City Subdistrict region, and administratively the Bastiong Karance Kelurahan is bordered by North side with Bastiong Talangame Village, West side with Ubo-Ubo Village, East side with Sea, and South side with Kayu Merah Village. (Profil Kota Ternate, 2013).

Demographic information shows that the total population of the Bastiong Karance urban village is 5,562. The number consisted of 2,785 men and 2,777 women with a sex ratio of 100.29. Based on the area and population, it is found that the population density in this village is 4,653 inhabitants / km2. The number of households is 1,187 families and the number of inhabitants in a family is 4.69 inhabitants. motorcycle taxis, civil servants, and housewives. (Bappeda Kota Ternate, 2012).

Fungal diagnosis can be made based on examination by various methods, namely the trap method, thinner, seedlings, hendrikill's, directly (using $10 \% \mathrm{KOH}$ ) and culture methods. However, in this study using the culture method, because the culture method is the definitive diagnostic method for most bacteria and fungi. The culture method is also included in the 
gold standard method to identify the types of fungi and bacteria, which is then followed by $10 \% \mathrm{KOH}$ staining, because to confirm the presence of fungi growing on culture media (Sedjawidada, et al, 2009).

Some researchers have succeeded in finding alternative media for fungal growth from protein sources, namely cowpea, green beans, and black soybeans (Ravimannan et al, 2014). In addition to research with protein sources, various carbohydrate sources have also been used successfully as alternative media such as cassava starch (Kwoseh et al, 2012), sago and uwi (Tharmila et al, 2011), potatoes and tuber palmirah (Martyniuk et al, 2011).

Previous study from Muhammad Rizal's in 2018 succeeded in optimizing the optimum concentration of Candida albicans growth on alternative potato media at a concentration of 300 grams per liter of media. Erpi Nurdin's study in 2018 found the most significant growth results of Candida albicans found in breadfruit alternative media, compared to alternative media for potatoes, cassava and sago.

The results of the breadfruit chemical analysis (Artocarpus altilis) showed variations among 18 populations of breadfruit origin (Kediri, banyuwangi, bone, shove, ternate, bali, etc.) with an average number of calories (62.65-110.98), carbohydrate ( $7.81-24.32 \%)$, protein (1.38$3.67 \%)$, fat (0.31-0.47\%), vitamin C (19.56-47.74 mg / 100g), phosphorus (10.14-35-68 mg / $100 \mathrm{~g})$, calcium (42.23-251.45 ppm), fiber (1.18-1.84\%), and iron (0.51 ppm). The results of the chemical analysis of breadfruit flour showed that the average carbohydrate content $(70.44 \%)$, protein (6.59\%), fat (1.29\%) and fiber (6.55\%). With high nutritional content, fruit breadfruit is very potential to be developed as an alternative medium in making fungal growth media. (Adinugraha and Susilawati, 2014).

Candida albicans examination can be done by three methods, namely the wet mount method, gram staining, and culture. The advantage of a wet mount examination can be done in a simple way, but direct examination should be done immediately after clinical material is obtained because Candida albicans develops rapidly at room temperature so that it can give an inappropriate picture. Direct examination with gram staining requires less time compared to examination with $\mathrm{KOH}$. This examination can see the fungus Candida albicans based on its morphology. The culture method can be used with the Potato Dextrosa Agar (PDA) medium with fungal growth appearing to be small, round, moist, white, with smooth and flat edges. (Vivi Keumala Mutiawati, 2016).

Candida albicans is a unicellular fungal species that is often encountered in human infections, so this fungal species is an object that is grown in a variety of alternative and semisynthetic media. In addition, rapid growth for 48 hours can be observed compared to multicellular fungi.

Medium is a material that consists of a mixture of food substances (nutrients) that function as a place to grow microbes. In addition to growing microbes, the medium can also be used to isolate, multiply, test physiological properties, and calculate the number of microbes (Cahyani, 2014).

One of the microorganisms that are often cultured in microbiology both in the food industry and in the agricultural industry is fungals. Fungal is one of microorganism which is often grown using PDA (Potato Dextrose Agar) media. Based on its composition, PDA is included in the semi-synthetic media because it is composed of natural ingredients (potatoes) and synthesis materials (dextrose and agar). Potatoes are a source of carbon (carbohydrates), vitamins and energy, dextrose as a source of sugar and energy, in addition to components that serve to compact the PDA medium. Each of the three components is very necessary for the growth and propagation of microorganisms, especially fungi (Cahyani, 2014). 
Fungal growth and development are generally greatly influenced by a number of factors including temperature, light, air, $\mathrm{pH}$ and nutrients such as carbon and nitrogen (Barnett and Hunter, 1998), and simple carbohydrates (Kelley, 1977). Semi-synthetic media such as PDAs have sufficient carbohydrate content so that they are good for fungal growth. This media is pretty much needed in fungal breeding both in the laboratory and in agriculture. However, the price of this media is quite expensive besides that not all chemical shops provide it, while the needs for PDA media are increasing so that another alternative is needed to replace the fungal culture media.

Based on the description above, the researchers intend to examine and find out the difference in the number of growth of the fungus Candida albicans isolated from the ear of fishermen in the village of Bastiong Karance in alternative breadfruit media and PDA semisynthetic media.

\section{Materials and Methods}

\section{Tools and Materials}

Petri dishes, rounded oceans, methylated lamps, methylates, microscopes, sterile tubes, autoclaves, glass objects and cover glass, $10 \% \mathrm{KOH}\left(\right.$ Merck $\left.^{\circledR}\right)$, incubators (Memmert ${ }^{\circledast}$ ), Potato Dextrosa Agar (PDA) (Oxoid $\left.{ }^{\circledR}\right)$, Breadfruit, Sucrose $\left(\right.$ Merck $\left.^{\circledR}\right)$, Agar $\left(\right.$ Oxoid $\left.^{\circledR}\right)$

\section{Methods}

Prepared tools and materials to be used, Inoculated samples from culture media, place on glass objects, Add 1 drop of $10 \% \mathrm{KOH}$, Cover with glass cover, Wait for 10 minutes, and observe under a microscope at 40x magnification (10x ocular lens and $4 x$ objective lens) and 400x (40x ocular lens and 10x objective lens). This microscopic examination was carried out to observe the morphology of the Candida $s p$ fungus seen using a microscope.

\section{Results}

The research data was obtained from sampling in the form of ear wax taken from the ears of fishermen in Bastiong Ternate City. While the sample examination was carried out at the Integrated Laboratory of Health Polytechnic Ministry of Health Ternate. From taking and examining samples taken from 46 fishermen, the following results were obtained (Table 1). From the results of examination of the sample in table 1 shows that from 38 respondents were found positive for Candida albicans.

Based on table 2 there are 38 positive samples of both synthetic and alternative fungi growth media that are overgrown with Candida albicans.

The research data were processed using paired T-test for comparison of the growth of Candida albicans taken from Fishermen's research subjects in semi-synthetic media (PDA) and alternative media. From the results of data processing, the significance level of the relationship is 0.000

\section{Discussion}

Some researchers have succeeded in finding alternative media for fungus growth from protein sources, namely cowpea, green beans, and black soybeans (Ravimannan et al, 2014). In addition to research with protein sources, various carbohydrate sources have also been used successfully as alternative media such as cassava starch (Kwoseh et al, 2012), sago and uwi (Tharmila et al, 2011), potatoes and tuber palmirah (Martyniuk et al, 2011). 
One of the microorganisms that are often cultured in microbiology both in the food industry and in the agricultural industry is fungi. Fungi is one of microorganism which is often grown using PDA (Potato Dextrose Agar) media. Based on its composition, PDA is included in the semi-synthetic media because it is composed of natural ingredients (potatoes) and synthesis materials (dextrose and agar). Potatoes are a source of carbon (carbohydrates), vitamins and energy, dextrose as a source of sugar and energy, in addition to components that serve to compact the PDA medium. Each of the three components is very necessary for the growth and propagation of microorganisms, especially fungi (Cahyani, 2014).

Fungal diagnosis can be made based on examination by various methods, namely the trap method, thinner, seedlings, hendrikill's, directly (using $10 \% \mathrm{KOH}$ ) and culture methods. However, in this study using the culture method, because the culture method is the definitive diagnostic method for most bacteria and fungi. The culture method is also included in the gold standard method to identify the types of fungi and bacteria, which is then followed by $10 \% \mathrm{KOH}$ staining, because to confirm the presence of fungi growing on culture media (Sedjawidada, et al, 2009).

Muhammad Rizal's research (2018) succeeded in optimizing the optimum concentration of Candida albicans growth on alternative potato media at a concentration of 300 grams per liter of media. Erpi Nurdin's research in 2018 found the most significant growth results of Candida albicans found in breadfruit alternative media, compared to alternative media for potatoes, cassava and sago.

The results of the breadfruit chemical analysis (Artocarpus altilis) showed variations among 18 populations of breadfruit origin (Kediri, banyuwangi, bone, shove, ternate, bali, etc.) with an average number of calories (62.65-110.98), carbohydrate (7.81-24.32\%), protein (1.38-3.67\%), fat (0.31-0.47\%), vitamin C (19.56-47.74 mg / 100g), phosphorus (10.14-35-68

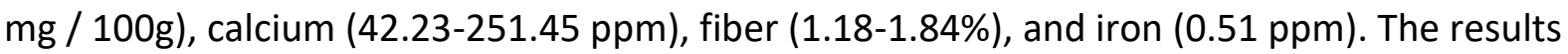
of the chemical analysis of breadfruit flour showed that the average carbohydrate content (70.44\%), protein $(6.59 \%)$, fat (1.29\%) and fiber (6.55\%). With high nutritional content, fruit breadfruit is very potential to be developed as an alternative medium in making fungal growth media. (Adinugraha and Susilawati, 2014).

Candida albicans examination can be done by three methods, namely the wet mount method, gram staining, and culture. The advantage of a wet mount examination can be done in a simple way, but direct examination should be done immediately after clinical material is obtained because Candida albicans develops rapidly at room temperature so that it can give an inappropriate picture.

Direct examination with gram staining requires less time compared to examination with $\mathrm{KOH}$. This examination can see the fungus Candida albicans based on its morphology. The culture method can be used with the Potato Dextrosa Agar (PDA) medium with fungal growth appearing to be small, round, moist, white, with smooth and flat edges. (Vivi Keumala Mutiawati. 2016).

Candida albicans is a unicellular fungal species that is often encountered in human infections, so this fungal species is an object that is grown in a variety of alternative and semisynthetic media. In addition, rapid growth for 48 hours can be observed compared to multicellular fungi.

Medium is a material that consists of a mixture of food substances (nutrients) that function as a place to grow microbes. In addition to growing microbes, the medium can also be used to multiply isolation, test physiological properties, and calculate the number of microbes (Cahyani, 2014). 
The work as fishermen also makes them often exposed to direct sunlight so that the body's temperature rises, the body will produce sweat and cause the ear wax to be disturbed. Ear canal is one of the places that is easily infected by fungus because the atmosphere is dark and warm makes the fungus easily grow because it gives high humidity which is suitable as a fungal habitat. In addition, most fishermen also pay little attention to personal hygiene and health.

Fungal growth and development are generally greatly influenced by a number of factors including temperature, light, air, $\mathrm{pH}$ and nutrients such as carbon and nitrogen (Barnett and Hunter, 1998), and simple carbohydrates (Kelley, 1977). Semi-synthetic media such as PDAs have sufficient carbohydrate content so that they are good for fungal growth. This media is pretty much needed in fungal breeding both in the laboratory and in agriculture. However, the price of this media is quite expensive besides that not all chemical shops provide it, while the needs for PDA media are increasing so that another alternative is needed to replace the fungal culture media.

Based on the research results of 46 samples examined there were 8 negative Candida albicans on semi-synthetic and alternative media, while 38 positive samples were overgrown with Candida albicans on both fungal growth media.

Alternative media derived from breadfruit, dextrose, and agar, are very well grown by fungi isolated from ear wax. In addition to Candida labicans, the media is also covered with multicellular fungi such as Aspergillus sp.

The research data were processed using paired T-test for comparison of the growth of Candida albicans taken from Fishermen's research subjects in semi-synthetic media (PDA) and alternative media. From the results of data processing, the significance level of the relationship is 0.000 . From the results of statistical tests it was found that the alternative media is very well used as a growth medium for Candida albicans fungi.

\section{Conclusions}

Based on the research that has been carried out, the following conclusions are obtained: There were 38 samples of respondents who were tested positive for Candida albicans on semi-synthetic media (PDA) and alternative media. Based on the data processing results obtained $p$ value $0,000<0.05$ which indicates that there is a very significant difference in the growth of Candida albicans between semi-synthetic media (PDA) and alternative media.

\section{Acknowledgements}

The authors would also like to thank National Maize Research Program Rampur (NMRP), Rampur, Chitwan, Nepal for the provision of research materials financial supports for conducting this research.

\section{References}

Adam, 2007, Buku Ajar Ilmu Penyakit THT, Pusat Penerbit Ilmu Penyakit Telinga Hidung Tenggorok Fakultas Kedokteran Universitas Indonesia, Jakarta.

Berkhout, R., 2013. Kejadian Koloni Jamur Pada Penderita Otitis Dengan Berbagai Penyebab Di Poliklinik THT Rumah Sakit Pendidikan Unhas.). Bagian Telinga Hidung Tenggorokan) : Makassar. 
Dwi Hapsari, 2011 Penghentian pemakaian antibiotik topikal dan antibiotik jamur lokal atau sistemik. Akademi Analis kesehatan Muhammadiyah.

Fansulal et al, 2007. Distribusi jamur penyebab otomikosis : Bagian Ilmu kesehatan Fakultas Kedokteran Unuversitas indonesia pp. 282-4

Gaffar, Abdul. 2010. Candida albicans. Faculty Of Medicine University Of Riau : Pekanbaru

Hasnawati, Arwin. 2012. Akademi Analis Kesehatan Muhammadiyah Makassar: Dalam Masyitha Mawangi (Ed.), Penuntun Praktikum Mikologi Medik (hal 5-31), Makassar.

Humaira, C. F. 2012. Prevalensi Otomikosis Pada Mahasiswa PSPD FKIK UIN Syarif Hidayatullah Jakarta dan Faktor yang Mempengaruhi Di Fakultas Kedokteran. Jakarta : Program Studi Pendidikan Dokter Universitas Islam Negeri Syarif Hidayatullah.

Jojo, 2012, Struktur Reproduksi Jamur jurnal mikologi Fakultas Kedokteran Universitas Indonesia: Jakarta.

Judith, 2009 Buku saku diagnosis kesehatan jakarta : EGC

Kawilarang, dkk. 2013. Buku Ajar Mikologi Kedokteran.Airlangga University Press-Surabaya.

Koes Irianto. 2013. Mikrobiologi Menguak Dunia Mikroorganisme. Yrama Widya : Bandung

Koes Irianto. 2014. Bakteriologi, Mikologi, dan Virologi. Edisi I. Penerbit Alfabeta : Bandung.

Komariah, Satori. 2012. Metode Penelitian Kualitatif. Alfabeta : Bandung

Kreger, R, 2015. Kejadian Koloni Jamur Pada Penderita otitis Dengan Berbagai Penyebab Di Poliklinik THT Rumah Sakit Pendidikan Unhas.). Bagian Telinga Hidung Tenggorokan) : Makassar.

Larone DH. 2011. Medically Important Fungi ; A Guide to Identification. $5^{\text {th }}$ Edition.ASM PressWashington DC.

Lindawati, dkk. 2015. Pemeriksaan Mikrobiologi. Fakultas Kedokteran, Universitas Airlangga :Surabaya.

Magdalena, Maria. 2009. Candida albicans. Fakultas Kedokteran : USU

Rahma Faradiana, 2016. Pemanfaatan sumber Karbohidrat (Umbi Suwag dan Umbi Kimpul) sebagai media substitusi pertumbuhan jamur.Universitas Muhammadiyah Surakarta.diakses pada tanggal 25 Februari 2018

Rusmarjono., 2010. Buku Ajar Kesehatan Telinga Hidung Tenggorok Kepala Leher. Jakarta : Balai penerbit FKUI.

Saryono. 2010. Metodologi Penelitian Kesehatan. Mitra Cendikia Press: Jogjakarta.

Sedjawidada R, dkk., 2009. Bagian Telinga Hidung Tenggorokan Fakultas Kedokteran Universitas Hasanuddin. Kejadian Koloni Jamur Pada Penderita Otore Dengan Berbagai Penyebab Di Poliklinik THT Rumah Sakit Pendidikan Unhas, 1 (1): 1-14.

Sukardi, 2009. Ilmu Penyakit Telinga Hidung Tenggorok untuk Perawat. Fakultas Kedokteran Universitas Indonesia : Jakarta.

Supriatin, S, 2010. Candida dan Kandidiasis pada manusia. Balai Penerbit Jakarta: Fakultas Kedokteran UI. 
Vivi Keumala Mutiawati. 2016. Pemeriksaan Mikrobiologi Pada Candida albicans. Jurnal Kedokteran Syiah Kuala. Diakses tanggal 28 Febriari 2018

Windi, 2017. Identifikasi Jamur Aspergillus sp. Pada Swab Liang TelingA Para Petani Di Kelura han Gambesi Kecamatan Ternate Selatan

Windu, 2010. Laporan Kasus Otomycosis. Jurnal Kesehatan Andalas, 3(2): 101-106.

Yudhi, 2010. Laporan Kasus Otomycosis primer dan sekunder. Jurnal Kesehatan 


\section{TABLE AND FIGURE}

Table 1. Results of the examination of Candida albicans in the ear cerumen against semisynthetic media and alternative media

\begin{tabular}{|c|c|c|c|c|c|}
\hline \multirow[b]{2}{*}{ No. } & \multirow[b]{2}{*}{ Name (Initial) } & \multirow[b]{2}{*}{$\begin{array}{l}\text { Sample } \\
\text { Code }\end{array}$} & \multirow[b]{2}{*}{$\begin{array}{l}\text { Age } \\
\text { (Year) }\end{array}$} & \multicolumn{2}{|c|}{ Growth of Candida albicans (Colony) } \\
\hline & & & & $\begin{array}{c}\text { Semi Sintetic Media } \\
\text { (PDA) }\end{array}$ & $\begin{array}{c}\text { Alternative } \\
\text { Media }\end{array}$ \\
\hline 1 & Tn. HR & NC1 & 37 & 2 & 1 \\
\hline 2 & Tn. HN & NC2 & 36 & 3 & 3 \\
\hline 3 & Tn. RF & NC3 & 37 & 5 & 6 \\
\hline 4 & Tn. MC & NC4 & 28 & 0 & 0 \\
\hline 5 & Tn. FL & NC5 & 41 & 17 & 2 \\
\hline 6 & Tn. IR & NC6 & 35 & 1 & 2 \\
\hline 7 & Tn. HM & NC7 & 36 & 247 & 155 \\
\hline 8 & Tn. JL & NC8 & 46 & 54 & 31 \\
\hline 9 & Tn. DL & NC9 & 48 & 24 & 24 \\
\hline 10 & Tn. RL & NC10 & 39 & 43 & 31 \\
\hline 11 & Tn. HS & NC11 & 35 & 5 & 5 \\
\hline 12 & Tn. MM & NC12 & 35 & 7 & 5 \\
\hline 13 & Tn. MR & NC13 & 37 & 0 & 0 \\
\hline 14 & Tn. DD & NC14 & 40 & 5 & 7 \\
\hline 15 & Tn. BK & NC15 & 35 & 48 & 20 \\
\hline 16 & Tn. LD & NC16 & 36 & 32 & 31 \\
\hline 17 & Tn. HD & NC17 & 37 & 21 & 13 \\
\hline 18 & Tn.KL & NC18 & 36 & 14 & 10 \\
\hline 19 & Tn. AD & NC19 & 48 & 0 & 0 \\
\hline 20 & Tn. DE & NC20 & 49 & 3 & 6 \\
\hline 21 & Tn. OT & NC21 & 37 & 21 & 11 \\
\hline 22 & Tn. IS & NC22 & 39 & 0 & 0 \\
\hline 23 & Tn. AE & NC23 & 37 & 57 & 20 \\
\hline 24 & Tn. AD & NC24 & 28 & 122 & 23 \\
\hline 25 & Tn. JU & NC25 & 25 & 23 & 23 \\
\hline 26 & Tn. DN & NC26 & 45 & 19 & 2 \\
\hline 27 & Tn. BM & NC27 & 44 & 299 & 5 \\
\hline 28 & Tn. RT & NC28 & 37 & 76 & 1 \\
\hline 29 & Tn. HL & NC29 & 34 & 0 & 0 \\
\hline 30 & Tn. WD & NC30 & 20 & 0 & 0 \\
\hline 31 & Tn. EL & NC31 & 31 & 4 & 2 \\
\hline 32 & Tn. AL & NC32 & 41 & 0 & 0 \\
\hline 33 & Tn. DS & NC33 & 32 & 17 & 17 \\
\hline 34 & Tn. DO & NC34 & 35 & 0 & 0 \\
\hline 35 & Tn. RF & NC35 & 27 & 5 & 11 \\
\hline 36 & Tn. UC & NC36 & 38 & 199 & 2 \\
\hline 37 & Tn. ZH & NC37 & 46 & 5 & 9 \\
\hline 38 & Tn. ON & NC38 & 48 & 3 & 3 \\
\hline 39 & Tn. JM & NS39 & 45 & 7 & 10 \\
\hline 40 & Tn. ER & NS40 & 43 & 6 & 21 \\
\hline 41 & Tn. YD & NS41 & 45 & 8 & 7 \\
\hline 42 & Tn. ST & NS42 & 44 & 3 & 3 \\
\hline 43 & Tn. AL & NS43 & 36 & 299 & 299 \\
\hline 44 & Tn. RS & NS44 & 46 & 2 & 4 \\
\hline 45 & Tn. AM & NS45 & 46 & 3 & 3 \\
\hline 46 & Tn. FI & NS46 & 30 & 1 & 2 \\
\hline
\end{tabular}

Table 2. Distribution and frequency of Salmonella typhi on children's hygiene

\begin{tabular}{cccc}
\hline \multirow{2}{*}{\begin{tabular}{c} 
Candida albicans \\
\cline { 2 - 4 }
\end{tabular}} & \multicolumn{2}{c}{ Quantity } & Total \\
\hline $\begin{array}{c}\text { Segative } \\
\begin{array}{c}\text { Semi-Syntetic Media } \\
\text { (PDA) }\end{array}\end{array}$ & 8 & 38 & 46 \\
\hline
\end{tabular}




\begin{tabular}{llll}
\hline Alternative Media & 8 & 38 & 36 \\
\hline
\end{tabular}

Table 3. T-test measurements for the growth of Candida albicans on semi-synthetic media (PDAs) and alternative media

\begin{tabular}{|c|c|c|c|c|c|c|}
\hline & \multicolumn{6}{|c|}{ Test Value $=0$} \\
\hline & \multirow[b]{2}{*}{$\mathrm{t}$} & \multirow[b]{2}{*}{$\mathrm{df}$} & \multirow{2}{*}{$\begin{array}{c}\text { Sig. } \\
\text { (2-tailed) }\end{array}$} & \multirow{2}{*}{$\begin{array}{c}\text { Mean } \\
\text { Difference }\end{array}$} & \multicolumn{2}{|c|}{$\begin{array}{c}95 \% \text { Confidence } \\
\text { Interval of the } \\
\text { Difference }\end{array}$} \\
\hline & & & & & Lower & Upper \\
\hline Fungus growth & 12.728 & 45 & .000 & .783 & .66 & .91 \\
\hline Fungus growth & 14.620 & 45 & .000 & .826 & .71 & .94 \\
\hline
\end{tabular}

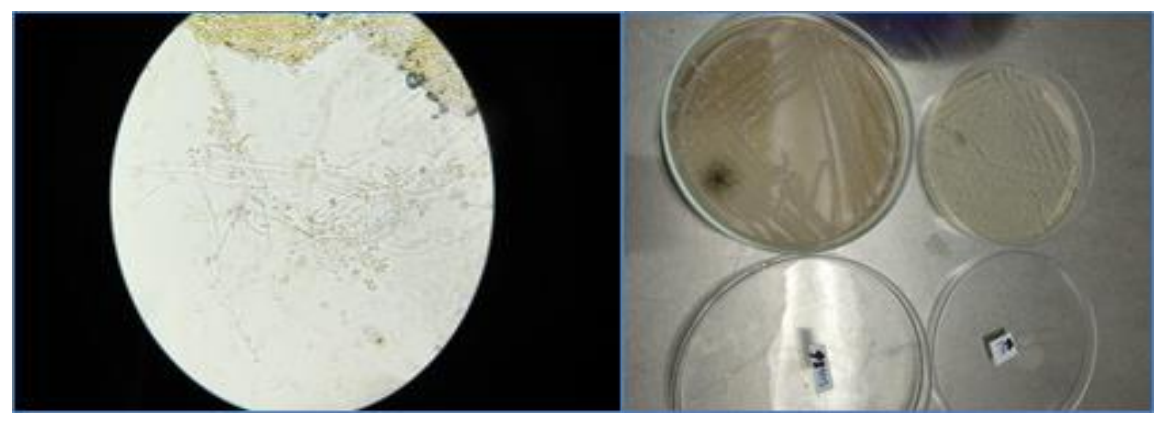

Figure 1. Candida albicans Colonies and Microscopes

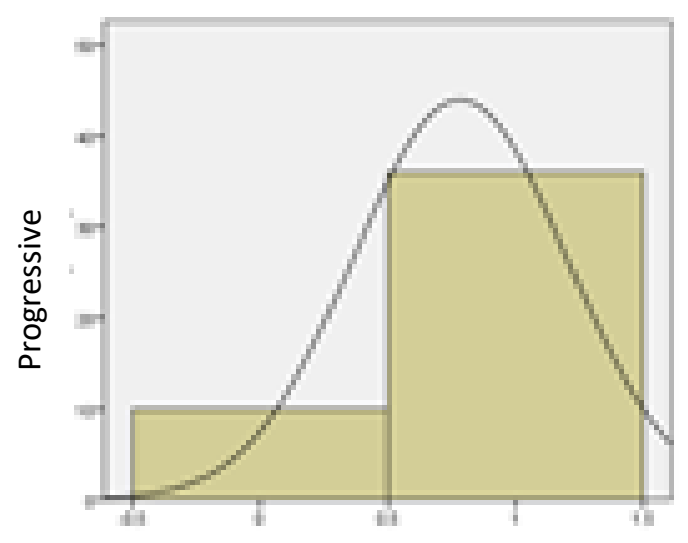

Fungal Growth

Figure 2. Growth Diagrams of Candida albicans on semi-synthetic media (PDA) and alternative media 